\title{
HUMAN RESOURCE MANAGEMENT FOR SUSTAINABLE MICROFINANCE INSTITUTIONS IN NIGERIA
}

\author{
O. M. IKEANYIBE
}

(Received 27, November 2007; Revision Accepted 7, February 2008)

\begin{abstract}
Microfinancing in Nigeria has developed from the traditional informal groups through direct government intervention to domination by private sector owned and managed institutions. Despite its long history, the sector has not witnessed the existence of sustainable institutions. This prompted the Obasanjo regime to adopt a more formal policy to improve the sector. Various reasons have contributed to the unsustainability of microfinance institutions in the country. But the human resource factor is considered significant among all these. Using a historical and content analysis methods, this paper undertakes to examine the effect of poor human resource management generally on organizations and more specifically on the development of microfinance institutions in Nigeria. The paper analyzes some of the provisions of the Microfinance Policy, Regulatory and Supervisory Framework for Nigeria (2005) to explain in simple terms the human resource implications of some of the roles stipulated for key stakeholders of the microfinance institutions. The paper discovers that some of the factors that have affected the sustainability of microfniance institutions in Nigeria include poor skills development and lack of business initiative among the potential clients of the institutions, poor staff development, utilization and compensation in the institutions themselves and ineffective supervision and control of operators by the regulatory authorities. It is therefore, recommended among others actions that sustainability in the sector should preeminently concentrate efforts in capacity building of the poor, improvement of supervision and regulation by monetary authorities and ensuring proper employee development, utilization and compensation. These recommended actions must be collaborated by the key stakeholders whose roles were analyzed.
\end{abstract}

KEY WORDS: stakeholders, skills development, business entrepreneurship ability, employee development, employee welfare, and commitment.

\section{INTRODUCTION: A CONCEPTUAL AND THEORTICAL DISCOURSE}

\subsection{Introduction:}

Micro-Finance Institutions (MFIs) are meant to take care of the credit needs of some special class of citizens- the poor, which constitute a high percentage of the Nigerian population (about $70.2 \%$ ). Yet, efforts over the years to establish viable microfinance institutions have not yielded significant results in terms of their sustainability. This has informed the launching of the Microfinance Policy, Regulatory and Supervisory Framework for Nigerian in December 2005. The policy is expected to be a new beginning for microfinance in the country. It has addressed comprehensively most of the issues that have contributed to poor performance in the sector and has made ample provisions for improvement.

Commenting on the poor performance of the erstwhile community banks and other previous microfinance and development institutions, the Central Bank of Nigeria in the Policy document observes that:

The prolonged sub-optimal performance of many existing community banks, microfinance and development finance institutions is due to incompetent management, weak internal controls and lack of deposit insurance scheme. Other factors are poor corporate governance, lack of well-defined operations and restrictive regulatory/supervisory requirements $(\mathrm{CBN}$, 2005a: 6)

O. M. Ikeanyibe, Department of Public Administration and Local Government Studies, University of Nigeria, Nsukka, Enugu State 
There is no doubt that some of these problems have significant correlation to issues of human resource management. This paper therefore investigates the human resource management aspect of the problems of microfinancing in Nigeria. Specifically, the paper seeks to explain some human resource concerns that derive from the responsibilities provided for key stakeholders. The methodology adopted is largely a critical analysis of the existing relevant documents including the new microfinance policy launched in 2005. There are other empirically derived publications and commissioned papers from which data are sourced.

The paper is organized in four sections. Section one includes the introduction, the conceptual explications and a theoretical discourse on the theory of human resource preeminence that serves as the framework of analysis. Section two provides a brief overview of microfinancing in Nigeria. Section three analyses the human resource management effect on microfinance institutions development in Nigeria and the new roles as they relate to key stake holders. The final section concludes the paper and highlights some recommendations derivable from the analysis.

\subsection{The concept of Human Resource Management}

The concept of human resource management (HRM) is a new label for the traditional managerial concept of personnel management (PM).

The concept has developed in recent years as a broad encompassing field of study that incorporates and synthesizes elements from personnel management, organizational behaviour and industrial and labour relations, building on broader concepts and insights from a variety of cognate disciplines including psychology and sociology amongst others (Poole and Warner, 2001).

Decenzo and Robbins (1998) simply explain human resource management as being concerned with the 'people' dimension in management, and this people dimension has to do with their acquisition, developing their skills, motivating them to high levels of performance, and ensuring that they continue to maintain their commitment to the organization. This definition apart from the emphasis on commitment, has not said much about what distinguishes human resource management from personnel management, which is also defined as that part of management that is concerned with people at work and with their relationships within the organization. Armstrong (2004:1) defines HRM as the "strategic and coherent approach to the management of an organization's most valued assets: the people working there who individually and collectively contribute to the achievement of its objectives".

The major problem in understanding the concept of HRM is first to distinguish it from that of personnel management (PM). While some scholars will regard their difference only in terms of label and opinion than anything factual (Torrinton and Hall, 1991), others believe that the differences are substantial. Storey for instance, is known to have listed twenty-seven differences between the two concepts. Summarizing these differences Guest (1987: 16) submits that:

Compared with personnel management, human resource management is concerned more with a long term perspective; the psychological contract based on commitment rather than external control; a unitarian rather than a pluralist perspective; an organic rather than a bureaucratic structure; integration with line management rather than specialist or professional roles and maximum utilization rather than cost-minimisation.

The concept of HRM incorporates the traditional functions of personnel management that has to do with the recruitment, selection, training and development, compensation, promotion, discipline management-labour relations etc. More importantly, it seeks to perform these functions in a different way that enlists personnel satisfaction and commitment. HRM more than PM seeks to perform those same activities that are involved in managing human beings in an organizational setting more effectively for the benefit of the individual, society and the business (Schuler, 2001). The American Society for Training and Development (ASTD) identifies nine-activity area as constituting the field of HRM. These areas and their focal activities are usually illustrated with what is known as the Human Resource Wheel. The components of the Human Resource Wheel are human resource planning, selection and staffing, training and development, organization and development, organization and job design, compensation/benefits, employee assistance, union/labour relations and personnel research and information systems. 


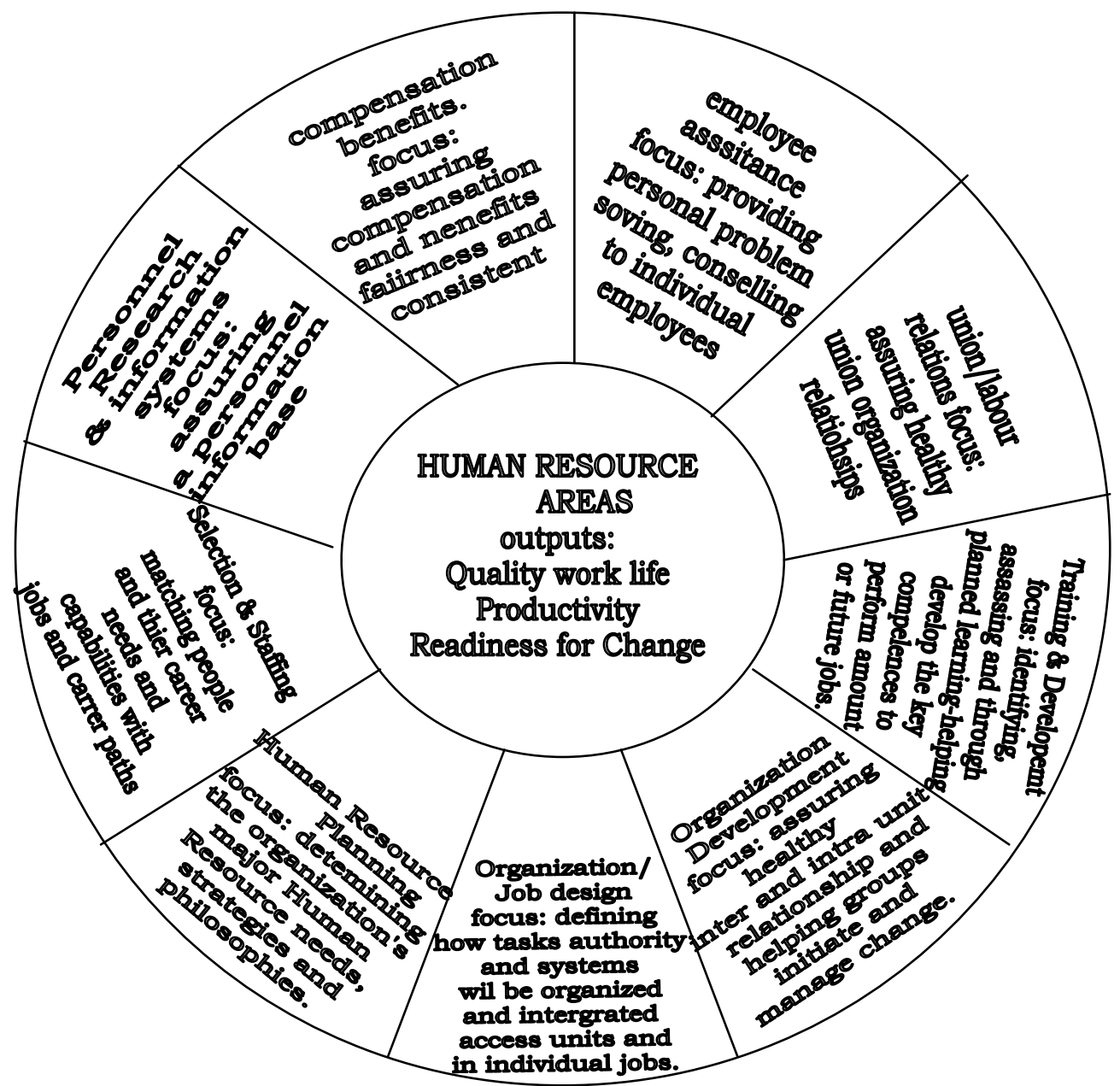

Source: American Society for Training and Development (1983:23) as reprinted with permission in DeCenzo and Robbins (1998: 8).

Fig. 1: Human Resource Wheel

Though the American Human Resource Wheel may have been comprehensive enough to include significant HRM activities, it is observed that it is specifically addressing the HRM at the enterprise/organizational level or what is usually referred to as the micro level. But Yesufu (2000) reveals that human resource can equally refer to the entire population of a nation or a section thereof as potential labour force or productive resources. It is therefore necessary that the concept of human resources be also understood at the macro or national level. At this level, human resource management goals cover such issues as population and labour force analysis; labour policy, institutions and legislation; manpower planning and brain drain phenomenon; incomes and poverty; social security including housing and health; women and child labour; and organized labour movement, that is, trade union and industrial relations (Yesufu, 2000). The important aspect of HRM that features in this paper at this level of conceptualization is education, skills acquisition, human capacity building in all ramifications, and provision of social welfare. HRM at the macro level therefore can be defined with Anyanwu, Oyefusi, Dimowo aand Oaikhenan (1997:286) to be the process of determining the policies and programmes that will develop, distribute, and utilize human resources with a view to attaining a nation's broader goals of socio-economic and political development. 
It includes the regulation of the employment market and supervision of the activities of certain enterprises to ensure that the government employment policies in various sectors are achieved. The government has the primary duty of regulating labour. Such labour legislations like Wages and Salaries Act are meant to initiate good employment policy and to control the demand and supply of labour evenly within the economy. In other words,

The essence of a good employment policy is to maintain the highest possible (the optimum) level of employment, institute productivity promotion measures, and thereby through higher and better spread of incomes, reduce poverty and improve the citizen's welfare. (Yesufu, 2000: 76).

The concept of HRM as applied in this paper is loosely understood to incorporate (i) the role of stake holders at the macro level to equip the microfinance clients with the skills, capacities and empowerment to benefit from the services provided by the microfinance institutions; (ii) the role of relevant stakeholders to control and regulate the activities of Microfinance Institutions Operators to imbibe the principles of good governance; and (iii) the role of relevant stakeholders to ensure the attraction, retention and adequate motivation of employees of the MFIs to secure their full commitment to the progress of their enterprises.

\subsection{The concept of Microfinance Institutions}

Microfinance is defined "as a development tool used to create access for the economically active poor to financial services at a sustainably affordable price" (CBN Briefs, 2004-2005:66). Ehigiamusoe observes that initially the issue of microfinancing was understood only in terms of credit provision i.e. working capital loans. But with time, the concept of microfinance has expanded in scope to include the provision of various kinds of financial services like "savings, consumer's loans, micro-leasing, micro insurance, money transfers and micro-investment services" (Ehigiamusoe, 2006a: 4). Prisms (2005), further classifies microfinance activities in Nigeria into three, namely, financial services (loans, deposits, leasing etc.); non-financial services (classes on literacy, numeracy, nutrition, health, etc.); and business development. There is a fundamental assumption in microfinancing that the poor know what to do but have only remained poor because they operate from a slim economic base (Ehigiamusoe, 2006a). If this were true, then only financial services could solve the problem of poverty in Nigeria. But the obvious reality is that majority of the poor fundamentally lack elementary skills and entrepreneurship ability to initiate and manage a business. Microfinancing therefore must recognize the peculiar features and challenges of the poor and owners of small enterprises as people who lack not only financial resources, but also necessary skills and capacity to initiate and management business. Microfinance therefore, includes various programmes and processes through which the productive capacity of the poor is improved. Sundry assistance and empowerment strategies for the poor like assistance programmes for small farms, public investments in rural infrastructure, health facilities, schools and the like geared towards alleviating poverty may be regarded as essential aspects of microfinance (Hazell and Lutz, 1998). This is relevant when these services are provided with the aim to improving the productive capacity of the poor.

The concept of microfinance institution (MFI) therefore will refer to an institution that provides small financial services to the poor or other non-financial resources that would equip the poor for economic empowerment. It is defined as the entire flexible structures and processes by which financial services are delivered to owners and potential owners of micro-enterprises on a sustainable basis.

Microfinance institutions can also be understood in terms of informal, semiformal and formal, privately owned, non-governmental and government established institutions. The informal institutions are the traditional self-help groups or rotating savings and credit association types (CBN, 2005a). The semi formal within the Nigeria context is construed to include registered organizations such as cooperatives or nongovernmental organizations registered under the Trusteeship or any other law. The formal financial institutions are the modernized institutions that operate within the integrated mainstream of national financial system. They include banks such as the erstwhile community banks and government established development financial institutions. Both the semiformal and formal institutions operate in accordance with some level of governmental laws establishing and regulating their activities. But prior to the new policy, most of the activities of the semi formal institutions were not regulated or supervised by the regulatory authorities. 
The Microfinance Policy, Regulatory and Supervisory Framework for Nigeria, (CBN, 2005a), describes microfinance institutions as those that provide financial services to the poor who are traditionally not served by the conventional financial institutions. Characteristically, such institutions whether formal, semiformal or informal are distinguished from other formal financial institutions by the smallness of their financial transactions (loan or savings); absence of assetbased collateral as security for credit advancement because of the inability of their clients to provide one; and the simple nature of their operations also because of the literacy level of their clients. The need for a reform in the sub sector according to the CBN (2005a) is to initiate a policy that will recognize the existing informal institutions and bring them within the supervisory purview of the CBN so as to enhance monetary stability and expand the financial infrastructure of the country to meet the financial requirements of the Micro, Small and Medium Enterprises (MSMEs).

The new policy requires the conversion of all MFIs to Microfinance Banks to ensure control and supervision of their operations. In accordance with the requirements of the policy, MFI would mean "any company licensed to carry on the business of providing microfinance services, such as savings, loans, domestic funds transfer, and other financial services that are needed by the economically active poor, micro, small and medium enterprises to conduct or expand their businesses as defined by these guidelines" (CBN, 2005a: 3). This is our understanding of the concept in the paper. But it is also significant within the conceptualizations made here to remark that very many registered cooperatives, semiformal and informal institutions still qualify as MFIs and are not likely to meet the stipulation for conversion.

\subsection{Theoretical Framework of Analysis}

The theory of human resource preeminence in sustainable development is used as the framework of analysis in this paper. The classical economists propounded that land, capital and labour were the basic factors of production. Labour is usually associated with the human person and qualifies him as a resource i.e. "principal source of wealth or income of a country or institution" (Chambers, 1996). Labour occupies prime place in production because "land would remain uncultivated, and capital would lie idle and perhaps, would never even have been invented or accumulated, but by and for the utilization of labour" (Yesufu, 2000:1). Harbison has summarized the claims of this theory when he asserts that

Human resources-not capital noir income nor material resources - constitute the ultimate basis for the wealth of nations. Capital and natural resources are passive factors of production; human beings are the active agents who accumulate capital, exploit natural resources, build social, economic and political organizations and carry forward national development. (Harbison, 1973:3)

Thus while not denying the importance of other resources in the productive process, the theory assumes that human beings are the most important assets of a nation or organization. Man as the source of labour potentially possesses limitless skill, knowledge and capabilities that can be developed, harnessed and managed to ensure national, sectoral or organizational survival and progress. Basically, HRM entails two interrelated concepts- human resource development and human resource utilization. Human resource development entails activities aimed at enabling the individual to realize his or her potentials for productive growth in the nation or organization while utilization signifies activities to get the individual's utmost performance. Since development implies investment, utilization entails getting the desired returns for as Ojo, Aderinto and Fashonyin (1986:x) remark, "It is not enough for a country or industry to develop human resources; every effort should be made to utilize appropriately the manpower so developed." As a corollary to the above, for human resources to be properly utilized in some specific economic area (e.g. micro-finance sector), necessary development is required to equip those concerned for such roles and performances targeted.

\subsection{Application Of the theory to the Discourse}

From the above theoretical underpinning, it becomes glaring that efforts to institutionalize sustainable microfinance institutions must necessarily address the issues of developing the poor in terms of useful skills and capacities; the institutions that carry out the microfinance business must be regulated and supervised to ensure that their services are directed to the target group- the poor and are in accordance with the guidelines; and that they (MFIs) must have the capability of attracting and retaining competent personnel that will ensure their survival and progress. 
It is imperative that the theory of HRM conceptualized at the micro and macro levels be used to grasp this discourse. At the macro level, sustaining microfinance institutions within the scope of this paper requires that the poor be empowered with skills and capabilities that will make them suitable to use microfinance services; that effective regulation and supervision be carried out on operators; that adequate legislation be made on employment, labour issues and salary and wages for the sector. At the micro level, acquisition of qualified personnel for the MFIs, developing the skills and abilities of the personnel, motivating them to high levels of performance and maintaining their commitments to the MFIs are some of the issues discussed. At this level HRM theory underscores the need to address the welfare of MFls employees to achieve the bottomline goals of survival, sustainability, growth, profitability, competitiveness and market penetration. Achieving these goals depends on MFIs' ability to attract qualitative people that can innovate better processes; people that can offer higher performance. Performance according to Lawler III (1973) is a function of ability and motivation.

Ability is explained to include all of the training, experience, talent, and aptitude that are necessary for good performance in a given situation, while motivation "is that energizing force that induces or compels and maintains behaviour" (Nwachukwu, 1988:181). Motivation as an aspect of human resource management is very important because possession of knowledge and skill required for a job is not a guarantee that such knowledge and skill will be applied in the job performance. Motivation helps to determine the level of commitment with which the employee seeks to acquire knowledge and skills through selfdevelopment and opportunities provided by the organization in terms of training. It determines the commitment with which he/she puts the knowledge or skill into the performance of his/her job. Ability must be complemented by motivational factors such as adequate remuneration, promotion, reasonable condition of service, good organization policy, the physical work environment etc. As Boxall and Purcell note, people perform well when:

- They are able to do so (they can do the job because they have the necessary abilities and skills);

- They have the motivation to do so (they will do the job because they want to and are adequately incentivized);
-

Their work environment provides the necessary support and avenues for expression (for example, functioning technology and the opportunity to be heard when problems occur) (Boxall and Purcell as cited by Armstrong, 2004:5).

There is no doubt therefore that microfinance institutions will perform better when they have attracted qualified people and are able to motivate them well. In this regard, Onyene (2000:138) admonishes that "before an individual can be made to improve his performance his interest, needs, and desires have to be considered." Microfinance institutions must be seen to employ qualified personnel, train and retrain them to meet changing circumstances and above all take good care of them through the provision of adequate employee compensation and welfare.

\section{BRIEF OVERVIEW OF MICROFINANCE INSTITUTIONS IN NIGERIA}

Microfinance is not new in Nigeria. Historically,

the practice of microfinance in Nigeria is culturally rooted and dates back several centuries. The traditional microfinance institutions provide access to credit for the rural and urban, low-income earners. They are mainly the informal Self-Help Groups (SHGs) or Rotating Savings and Credit Associations (ROSCAs) types. Other providers of microfinance services include savings collectors and cooperative societies (CBN, 2005a: 4).

The informal arrangements are known in the Northern part of the country as 'adashi', 'esusu' in the West and 'itutu' in the East. Various other terminologies have been found to refer to these traditional systems not only in the three major ethnic groups but in all other parts of the country. Apart from the informal institutions which are pervasive, but 'have limited outreach due primarily to paucity of loanable funds' (CBN, 2005: 4), there are also the semi formal and formal institutions as have been conceptualized above, the operations of semi formal microfinance institutions in Nigeria are relatively new, as most of them were registered after 1981. Most of these operated as nongovernmental organizations.

Until 1990 when the community-banking scheme was inaugurated, the government had 
relied much on direct intervention measures or government financed institutions as the medium to solving microfinance problems. The direct intervention measures are usually based on a topdown or trickle- down (TDS) non-profit-oriented approach. Notable among the programmes in this category that have been tried in Nigeria were the development finance institutions (DFIs).

Between 1964 and 1977, various development finance institutions (DFIs) were established at both the national and state levels in Nigeria. The national DFls included the Nigerian Industrial Development Bank (NIDB), Nigerian Bank for Commerce and Industry (NBCl), Nigerian Agricultural and Cooperative Bank (NACB) and Federal Mortgage Bank of Nigeria (FMBN) (Anyanwu, 2004: 11)

Other measures initiated by the government to combat the microfinance problem were the Rural Banking Programme, Sectoral Allocation of Credits, Agricultural Credit Guarantee Scheme, Cooperative Bank Limited, National Directorate of Employment, Nigerian Agricultural Insurance Corporation, the Peoples Bank, Family Economic Advancement Programme and Poverty Alleviation Programme and National Poverty Eradication Programme. Most of these programmes and institutions were primarily established to provide finance to the agricultural or other sectors. Many were also devised as means of poverty alleviation through the process of skills development and financial empowerment. But the limitations of these programmes were enormous. They include the problem of elite exploitation at the expense of the poor for whom they were directed to, concentration at the urban areas and nonpenetration, inconsistencies and lack of continuity in programme maintenance and insufficient funding. Okafor (1992) supports the view that the TDS approach "has been tried by many governments in Nigeria. But very limited positive results were achieved in the process. Indeed the TDS helped to create the enabling conditions for the rural-urban drift that has continued to afflict Nigeria into the 1990's". Similarly the CBN declares that

Microfinance services, particularly, those sponsored by government, have adopted the traditional supply-led, subsidized credit approach mainly directed to the agricultural sector and non-farm activities.... Although the services have resulted in an increased level of credit disbursement and gains in agricultural production and other activities, the effects were short-lived, due to the unsustainable nature of the programmes (CBN, 2005a: 4)

With the direction of governmental macro economic policy towards private sector driven initiatives since the Structural Adjustment Programme (SAP) introduced in 1986, the obvious focus on microfinancing has shifted to private sector ownership and management. Ehigiamusoe (2006b: 1) testifies, "microfinance is no longer the domain of charity. Microfinance has emerged as a thriving industry with investors with expectation (sic) returns on their investment." It is expected that this is the likely way to achieve sustainability.Sustainability according to Hazell and Lutz (1998:10) "requires that the value of capital stock not be depleted over time; hence sufficient income must be set aside or otherwise forgone to replenish any capital depreciation or losses incurred." Thus, microfinance services are expected to cover operating cost and yield surplus as profits for investors' remuneration and business expansion (Ehigiamusoe, 2006a).

The fate of the community banks, which at the climax of their establishment were 1368 in 1997 but has steadily declined to about 450 at the close of deadline to convert to Microfinance Banks on December 312007 reveals that the private sector-led microfinance institutions have not faired better. Quoting Oni, the Director Other Financial Institutions Department (OFID), the CBN department in charge of the Community Banks, MicroCapital expressed that

As at November ending 407 microfinance institutions had been approved by the CBN. By the end of the exercise, about 450 institutions would have scaled through out of a total of 700 . This means that about 250 institutions may not make it come December 31,2007 . Out of the 250 , a very large number (over 150) have actually closed down prior to the launching of the policy. So, we are looking at very few institutions to know those on ground so that we would see how we can come in to ensure that depositors' fund are protected. (MicroCapital, posted to Internet December 5, 2007)

The situation is similar for the non-governmental microfinance institutions or those we have qualified here as semiformal institutions. The UNDP/UNDCP Midterm Evaluation Programme of Microfinance in Nigeria (2007) shows that out of 
the 300 NGO-MFIs inventoried in the country, less than 10 would become microfinance banks as of January 1, 2008. Of course we have already mentioned that the informal institutions have limited outreach due to paucity of funding and are outside the purview of regulation and supervision.

It is consequent upon this messy situation in the sector that the new policy was introduced. Through the policy, the CBN and indeed the government hope to give more support to the microfinance institutions in Nigeria. And various roles have been articulated for various stakeholders. We now turn to the analysis of these roles especially as they concern issues of HRM already raised.

\section{SUSTAINING MICROFINANCE INSTITUTION THROUGH EFFECTIVE HUMAN RESOURCE MANAGEMENT}

\subsection{Effect of Poor Human resource Management in MFIs in Nigeria: A Review}

Many researchers and agencies have pinpointed human resource-related factors as major contributors to the obvious deterioration in the community banks. For instance, Manasseh (1995:5) feared that one of the major problems community banks have to face was recruitment of effective and appropriate manpower, partly due to their inability to adequately compensate their workers by way of salaries and fringe benefits. This fear was consequent upon the poor financial base of these banks. The executive secretary of the National Board for Community Banks, (NBCB), the second tier regulatory and supervisory body for the community banks admitted without equivocation that mismanagement was among the prominent problems that beclouded the community banking system for the ten years of its existence (NBCB, 2000). Ikeanyibe (2002), revealed more poignant human resource factors as the major problem of community banks. These issues range from poor training opportunities, poor and inadequate remuneration and conditions of service and inadequate regulation and supervision by NBCB. The NBCB was discovered to be the major trainer for community banks staff. The research revealed that $54.91 \%$ of the surveyed employees of community banks attended NBCB training, but only $37.7 \%$ acknowledged the usefulness of the training to their job performance. The training as offered by NBCB was to say the least, found to be defective, as it was not always based on the requirement of employees.
It was also discovered that the supervision of community banks were poorly done by the NBCB before the final take over of their regulation and supervision by the CBN (Ikeanyibe, 2002). There were irregular on-site inspection visits, lack of the will to punish erring operators and inability to enforce guidelines. More crucial was the issue of personnel remuneration and welfare. In the said research, we discovered that poor remuneration and bad conditions of service existed in most community banks. A consistent high average of $85.73 \%$ respondents opined on various test indices that job satisfaction and commitment were lacking as a result of the existing levels of remuneration and conditions of service. A sample opinion that summarizes the consistent views of respondents in our research on the nature of remuneration and conditions of service in the community banks was that of a discussant in a Focused Group Discussion (FGD) thus: "not only is salary poor, but you can also be thrown into the labour market anytime. And even if your work till your retirement age, no retirement benefit is assured" (Ikenyibe, 2002:130). A similar one by another discussant that attracts the support of many others in the FGD was: "most of us are paid with the view that we have the option to accept whatever we are paid or leave the employment" (Ikeanyibe, 2002:125).

If this situation were faced by the community banks that were regulated and supervised, one can imagine the fate of other microfinance institution that operated outside the purview of legal regulation and supervision- the semiformal or non-governmental and the informal ones. In a research commissioned by MicroStart Midterm Programme, the evaluators- Alter, Okeke and Onyeagocha, (2002) discovered that many of the 10 surveyed non-governmental microfinance institutions in Nigeria had salary structure that were unsustainable. The reason mainly was that salaries were maintained from donor funds, as the MFIs were not sustaining the salaries from the operations. The clients are poor people, who cannot bear the cost of staff salaries from the low interest rates they pay. When the salaries are too low, the MFIs will obviously face the risk of turnover and disgruntled staff. Thus, as clearly spelt out by the evaluators:

The current under market rate salary structure calls institutional sustainability into question-can the MFIs meet financial targets when paying higher wages? Although staff interviewed expressed enthusiasm about the program and commitment to the mission, evaluators 
found that they felt they are being underpaid. Whether this translates into staff turnover ... or low motivation and resentment, it is bound to translate directly into MFI performance (Alter, Okeke and Onyeagocha, 2002).

Apart from the peculiar problems that faced the institutions themselves, there is always the problem of lack of skills which poverty alleviation in particular and rural development efforts generally have faced in the country. It is true that clients of MFIs "are usually ill-equipped in terms of education and management skills. Olaitan (1995) opines that

Poverty in rural communities can be traced to two factors: low productivity and ignorance. Productivity in agriculture, technical trades, commerce and local craft is low because rural people employ traditional methods in production processes. Improved productive capacity requires that these rural people be equipped with skills and abilities which would enable them make effective use of modern techniques and technologies in their work roles. (Olaitan, 1995: 176).

Not only the productive and business skills; they also "lack necessary record keeping, planning and other basic management techniques. They are not versed in the art of feasibility study and market survey" (Ehigiamusoe, 2006b: 2)

It cannot therefore, be far fetched to see that inexperienced, unmotivated personnel cannot cope with the challenging, high-risk tendencies of microfinance business. This is because it is onerous on the employees of the MFls to supply these deficiencies of their clients or to be innovative enough to know how best to circumvent them without serious consequences for their institutions. Unfortunately, it is found by Alter, Okeke and Onyeagocha (2002) that some "MFls have no functional staff-i.e. accountant, internal audit function, MIS manager or computer specialist, cashier or financial manager" and "several of the MFIs are concerned about job security and staff retention". Microfinancelnsights (March, 2008) lends credit to this finding when it reports that:

It can be difficult to find employees with experience, and for some more advanced MFls here, finding staff who can handle the intricacies of creating new financial products and navigating complex regulations is a struggle.
There is no gain saying that issues of human resource management, some of which we have highlighted above must be addressed for a sustainable development of the microfinance subsector.

\subsection{Human Resource Management Roles for Major Stakeholders}

The new Microfinance Policy, Regulatory and Supervisory Framework for Nigeria (CBN, 2005a), has proposed various strategies of realizing the objectives of sustainable microfinance institutions in the country. A human resource management interpretation of some of these provisions is hereunder made for the key stakeholders in the sector.

\subsubsection{The Government as a Stakeholder}

The roles and responsibilities of the government as a stakeholder in realizing sustainable microfinance sub-sector boarders on its role as the overall pace setter of the macroeconomic environment in terms of the provision of the basic infrastructures, political and social stability. The government has been assigned the following roles and responsibilities towards the achievement of the policy goals in the microfinance sub sector:

* Ensuring a stable macroeconomic environment, providing basic infrastructures (electricity, water, roads, telecommunications etc), political and social stability;

* Fostering adequate land titling and other property rights sufficient to service the collateral needs of borrowers and financial institutions,

* Instituting and enforcing donor and foreign aid guidelines on micro-finance institutions to streamline their activities in line with the policy; and

* Setting aside an amount of not less than $1 \%$ of the annual budgets of state governments for on-lending activities of microfinance banks in favour of their residents.

$*$

There is no doubt that the above has shown the role of government to be purely that of enabler rather than a direct participator in delivering microfinance services as was done in the past. However, this enabler function is the more 
significant. For instance, the availability of necessary infrastructures will highly improve opportunities for the practice of various kinds of trades. Time is gone when agriculture is simply the target of microfinancing. It is now known that poor people can engage in other forms of occupation such as cottage industries like welding and wood construction, motor cycle transport, small businesses, various technical profession like vehicle, electrical and electronics technicians. Good roads, constant electricity, water; communication means, health facilities etc. are necessary for effective take off and sustenance of these various trades. Microfinance can work where opportunities for various trades and occupations are available to the poor. The government must continue to propel the economy in ways that create ample opportunities to absorb many poor people. Today many people are gainfully employed in communication businesses thanks to the immense opportunities created by the liberalization of the sector. It is however, sad to note that many poor people in rural Nigeria have not been provided with this opportunity probably because the Network Operators do not consider these areas profitable to extend their networks. As the government is privatizing almost everything, there is need to increase regulation to ensure that no sector of the country is marginalized. The rural areas must been given certain privileges in the provision of social and economic infrastructure if the government policy of poverty eradication is to been seen as sincere, since it is in the rural areas that the majority of the poor reside.

Furthermore, it will be shirking the responsibility for the government to absolve itself of any direct intervention in microfinance business especially in terms of education and skills acquisition programmes for the poor. While this function has been shifted to the public sector poverty alleviation agencies, which themselves are government agencies in the policy, it must be noted that these agencies cannot achieve much if the government does not take their mandate as a priority. Taking their mandate as a priority determines the level of financing they receive and also involves the government in a closer supervision and monitoring of what they do.

\subsubsection{Central Bank of Nigeria (CBN) as a Stakeholder}

The CBN has taken upon itself various roles and responsibilities to ensure the sustainability of MFIs. We shall only discuss those that concern the establishment, regulation and supervision of the MFIs. These are:

* evolving a clear microfinance policy that spells out eligibility and licensing criteria, provides operational/prudential standards and guidelines;

* evolving a microfinance sub-sector and institutional policies aimed at providing regulatory harmony, promoting healthy competition and mainstreaming microfinancing with formal intermediation

* adopting an appropriate regulatory and supervisory framework; and

* implementing appropriate training programmes for regulators, promoters and practitioners in the sub-sector, in collaboration with stakeholders.

The Micro finance policy contains well thought out strategies for the establishment and regulation of the MFIs. It is important however to appreciate the fact that poor supervision and regulation contributed to the failure of many community banks. One obvious fact about private sector owned MFIs is that most of their operators are in the business to make profit. Hence, they are not likely going to do most of the things that require successful lending to the poor like low interest lending, lending without collateral, small amount lending that takes almost the same efforts to process as bigger amounts, and lending to unattractive businesses e.g. agriculture, for fear of poor returns. There is the possibility too that many will go into the business of microfinancing as opportunity to get access to the proposed Microfinance Fund and other incentives proposed by the government without necessarily directing these benefits to the poor. Above all, sharp practices by major owners and key staff are one notable factor in failure of financial institutions.

To ensure that MFIs operate within the guidelines requires effective and efficient regulatory and supervisory activity from the regulatory bodies especially the CBN and Nigerian Deposit Insurance Corporation (NDIC). The fear is whether these regulatory bodies will be able to meet the demand as the number of MFIs increases. The current requirement of sending quarterly instead of monthly returns to CBN and NDIC is considered ineffective. On-site inspection should be at least on yearly basis to enable a confirmation of Returns with actual books of a MFI. Supervisory/ inspection visits need not be irregular 
or too long as had been the case in the past. Prisms (2005) has noted the importance of fiduciary responsibility of MFls. Though Prisms discusses this in the context of the role of the Board of MFIs, the obvious fact is that MFIs require consistent and effective fiduciary and overall management control because the insolvency of any MFI has adverse effect on the poor, the domestic as well as the international sector. The poor especially the low income microentrepreneurs, borrowers and savers, lack access to multiple sources of financing and are at greater risk than middle income savers if their savings are lost. Also, where the sector does not show any sustainable progress as a result of poor regulation and supervision, the public confidence in the system from both the domestic and international patronage in terms of savings deposit and intermediary funding diminish.

Another important role taken up by the $\mathrm{CBN}$ is that of implementing appropriate training programmes for regulators, promoters and practitioners in the sub-sector. The importance of this function cannot be overemphasized. Every organization requires the services of well-trained and experienced people to perform the activities that have to be done. Most universal banks today have their Training Schools and can afford to send their staff to other training establishments. We work on the assumption that MFIs have poor financial base that will require systematic subsidization of their training. The Other Financial Institutions Department (OFID) of the CBN has being doing enough to organize crucial training and workshops for microfinance banks operators in collaboration with Consultants and some Training Institutions like Financial Institutions Training Centre. It is however necessary to observe that the OFID is too engaged to pay adequate attention to everything concerning the MFIs since it also supervises and regulates other financial institutions like mortgage institutions. Yet, there is need to improve the tempo and curriculum contents of training in microfinancing. It is also necessary that training be decentralized to state and local government levels, to ensure that operators can attend easily without incurring huge transport and hotel accommodation cost for their juvenile institutions. The effect of the training must also be monitored and evaluated to ensure relevance. It is difficult that OFID will meet all these challenges alone.

\subsubsection{The Microfinance Institutions (MFIs) as Stakeholders}

The MFIs have been assigned the roles of :

* providing efficient and effective financial services, such as credit, deposits, leasing, and innovative transfer/payment services;

* undertake appropriate recruitment and retention of qualified professionals through transparent and competitive processes;

* adopt continuous training and capacity building programmes to improve the skills of staff;

* strictly observe their fiduciary responsibility, remain transparent and accountable in protecting savers' deposits; and

* comply with the rules and regulations as stipulated by the regulatory authorities.

The human resource management role for operators of MFIs is clear. As final remitters of the microfinance services, MFIs must recognize the need to acquire, develop, motivate and ensure that their employees are committed to their institutions. Commenting on the importance of the quality of personnel to a bank or financial institution, Bowden remarks that

People are everything in banking. They must develop the business concept for the bank, formulate a consistent strategy, and then implement the plans developed to carry on that strategic concept. People are the principal competitive weapon a bank has (Bowden, 1980:187).

It is important that operators of MFIs realize this and waste no time in adhering to the stipulations of the CBN Regulatory and Supervisory Guidelines for Microfinance Banks in Nigeria (2005b). Some of the stipulations of the guidelines include that

* at least two of the Board members shall have banking or related industry experience;

* the manager and departmental heads must have a university degree or its equivalent and/or professional qualification with at least seven and five years postqualification experience in banking or related industry respectively;

* the top management possesses the requisite certification on microfinance 
management from recognized institutions acceptable to the CBN. (CBN, 2005b: 15)

The Board of directors must note their important role as policy formulators and monitors regarding the good governance of their institutions. They must be seen to be guided by the highest standard of ethical behaviour if they have to enforce it on the management and employees. As articulated by Prisms (2005:1), good governance can help MFIs prevent fraud and mismanagement, promote sound decision making, avoid costly fines and litigation, create/maintain a positive corporate image, attract and retain clients and attract and retain financing and investment from the public, other banks, government intermediary funding or international donors. Prisms (2005) distinguishes four responsibilities of the board of a MFI. These are ensuring compliance with the institution's bylaws, procedures, and other legal requirements; ensuring management accountability by hiring competent professionals, establishing clear goals for them, monitoring their performance and confronting weaknesses when they arise; setting policy and providing strategic direction for the institution and collaborating with management towards achieving them; and continually assessing its own performance on a regular basis by renewing its membership with new well qualified directors, and evaluating its own processes for decision making.

\subsubsection{Public Sector Poverty Alleviation Agencies as Stakeholders}

The Microfinance policy recognizes the important role these agencies have to play not only in the overall effort to eradicate poverty but also in the central function of capacity building. The following responsibilities have been assigned to them:

* provision of resources targeted at difficultto-reach clients and the poorest of the poor;

* development of MFIs' activities nationwide;

* nurturing of new MFIs to a sustainable level; and

* collaborating/partnering with other relevant stakeholders.

Poverty alleviation and eradication programmes remain one direct intervention measure in which the government can be involved in microfinance activities. Often these poverty alleviation programmes are too programme-loaded that they loose focus and achieve very little. Usually they combine various schemes such as credit or financial assistance, rural and agricultural development, skills acquisition and capacity building and rural infrastructural provision schemes that become too unmanageable for a single institution. While such multi-scheme combination expresses the need for integration and coordination in the fight against poverty and improvement of the productive capacity of the poor, it overstretches the efforts of the implementing institution, which in any case does not receive commensurate financing from the government. It is equally a fact that usually the target clients of these agencies end up being political supporters rather than the real poor people.

A study of National Poverty Eradication Programme (NAPEP) in the first two years of its establishment (Nnadozie, 2003) for instance, revealed that many beneficiaries of skills acquisition programme for non graduatesCapacity Acquisition Programme (CAP) under the Youth Empowerment Scheme (YES) were poorly resettled. This is in addition to the insignificant number that benefited. The beneficiaries of the graduates programme, Mandatory Attachment Programme (MAP) received stipends months after their work. And the stipends were monthly salary for supposedly poor people who are supposed to use the stipend as maintenance expenses while they learn a trade in which they were attached. There is also the discovery that non-graduates, mainly party members were the real beneficiaries of even the graduate scheme.

While the current study is not intended to evaluate NAPEP, it is meant to reiterate the obvious- that direct intervention of government in microfinance especially as concerned with giving out credit or financial assistance, is not always sustainable, will greatly go to the wrong beneficiaries and the implementing agencies would usually complain of having funding problems since no amount would be adequate. There is need therefore of restructuring these agencies especially National Directorate of Employment (NDE) and NAPEP that still exist to concentrate on capacity building of the poor through skills acquisition training and business development projects. The role of trying to provide financial resources to the difficult to reach poor people could be done through special social security outfits that should operate on ward levels through community leaders 
to ensure that it is really the poorest people in the communities that are beneficiaries.

\subsubsection{Donor Agencies as Stakeholders}

By donor agencies, the policy refers to bilateral and multilateral institutions, NonGovernmental Organizations (NGOs), and missionaries with a pro-poor orientation. These offer free or subsidized funds, donations and technical assistance for the development of microfinance industry. The policy recommends that these donors channel their assistance to licensed MFIs or banks to ensure orderly resource injection, transparency and synergy. It needs to be added that these institutions especially the missionaries and churches could do more in the area of capacity building and vocational education of the poor. In the past, churches and religious groups were known to grant scholarships and establish affordable educational institutions. But today it seems they are more concerned with building cathedrals and pilgrimage-grounds. Even when some of them build schools and human development centers, the fees are placed so high that it is only the rich that can afford to send their wards to such institutions.

\section{CONCLUSION AND RECOMMENDATIONS}

\subsection{Conclusion}

The paper has tried to show the need for managing human resources efficiently and effectively as a necessary condition for sustaining the microfinance institutions in the country. The implication of this at the macro level for stakeholders is that reasonable efforts must be made in building the capacity of the poor in terms of equipping them with necessary skills, business ideas and opportunities. When these basic requirements are possessed, the poor can always seek for credit avenues that the MFls institutions can readily fulfill. But if credits are made available without these fundamental requirements, the consequence will be futile use of the credit made available to the poor. This will eventually lead to loss to both the poor and the MFI. Furthermore, at the macro level, human resource management is analyzed in terms of proper regulation of operators of microfinance and legislation to improve the attraction and retention of qualitative employees to the sector.

On the other hand the stakeholders of MFIs at the micro level must realize the importance of qualified, trained, motivated and committed employees in the pursuit of their organizational goals. The need for good governance must be recognized in the present competitive environment and the difficult task of dealing with the challenges of microfinancing. Achieving these objectives, require the coordination and cooperation of all the stakeholders of micro-finance as enlisted in the policy. The paper has stressed on key aspects of each stakeholder's roles and responsibilities especially as they relate to issues of human resource management.

\subsection{RECOMMENDATIONS}

To realize the critical goals of sustaining the microfinance institutions (MFIs), we reiterate the following recommendations.

* The government at all levels should show more commitment to infrastructural development at the rural areas. Most MFIs operate or are expected to operate at the rural areas where a good number of the poor people reside. Infrastructure such as electricity, water and roads are relevant to the establishment of cottage industries and businesses.

* The poverty alleviation agencies should focus more on programmes of skills development and vocational education. More could be achieved by developing people's skills and entrepreneurship abilities and linking them with MFIs for government subsidized interest rate credits. The combination of skills development, financial resettlement of beneficiaries and various other schemes by poverty alleviation agencies has not always worked.

* The CBN should increase the frequency and depth of its regulatory activities. The current system of rendering quarterly returns for the off-site inspection and irregular on-site inspection that may not take place for as long as two years, is not in the interest of effective supervision and regulation. The onsite inspection can be outsourced to various private sector Accounting Firms and carried out under the leadership of at least a staff of the relevant CBN department. This will minimize the problem of staff adequacy for the CBN department concerned especially as the number of MFIs increases. There is also the need to establish a separate department for MFIs in the CBN because of their expected number rather than the current situation of being under the OFID department that also controls and regulates other financial 
institutions. Inspection and supervision programme contents should include fundamental HRM factors and not just that of banking operations. There is need to discover unqualified Board and management staff as stipulated by the policy and dismiss/replace them; evaluate the adequacy of salary structure and other conditions of service and the level of training undergone by staff.

* Training Institution for the MFls could be established by the apex association of the microfinance institutions, which the policy assigns "to promote uniform standards, transparency, good corporate practices and full disclosures in the conduct of MFI businesses" (CBN, 2005a: 24). Or the Financial Institutions Training Centre could be empowered to establish a section or department that could personalize and adapt general banking theories to a unique curriculum for MFI training. There is need also that these trainings be more regular and decentralized to levels such as states or local governments for easy reach and affordability to the MFIs.

* The donor agencies such as non governmental agencies, missionaries and churches could assist the government by channeling their resources to building skills acquisition and vocational education centres as many do with formal educational institutions. These would complement the efforts of the government and poverty alleviation agencies in empowerment programmes for the poor.

\section{REFERENCES}

Agbobli, F.M. and Adamu, G., 2007. "UNDP/UNCDF Support to Development of a Sustainable Microfinance Sector: Midterm Evaluation Report 2007", http://web.ng.undp.org/publications/poverty /microfinance.pdf

Iter, K., Okeke, O. and Oneagocha, S., 2002. "MicroStart Nigeria Programme Midterm Evaluation May 2002", htpp://www.org/English/evaluations/pdf/Mic roStartNigeria.Eval.pdf

Anyanwu, C. M., 2004. Microfinance Institutions in Nigeria: Policy, Practice and Potentials", A Paper Presented at the G24 Workshop on 'Constraints to Growth in Sub Saharan
Africa', Pretoria, South Africa, http://www.microfinancegateway.org//files/ 33528_file28.pdf

Anyanwu, J.C., Oyefusi, A., Dimowo, F.A., and Oaikhenan, H., 1997. The Structure of the Nigerian Economy 1960-1997, Onitsha: Joanee Education Publishers Ltd

Armstrong, M., 2004. A Handbook of Human Resource Management Practice, $9^{\text {th }}$ ed., India: Kogan Page

Bowden, E. V., 1980. Revolution in Banking, Richmond, Virginia: Robert F. Dane Inc.

Central Bank of Nigeria (CBN), 2005a. MicroFinance Policy, Regulatory and Supervisory Framework for Nigeria, Onitsha: Adgozo Ltd.

CBN, 2005b. Regulatory and Supervisory Guidelines for Microfinance Banks (MFBs in Nigeria, Onitsha: Agozo Ltd.

Central Bank of Nigeria, 2004-2005. CBN Briefs: 2004-2005 Edition, Abuja: Research and Statistics Department, CBN

Damachi, U.G. and Diejomaoh, V. P., 1978. Human Resources and African Development, London: Praeger Publishers

DeCenzo, D.A. and Robbins, S. P., 2005. Personnel/Human Resource Management, 3rd ed., New Delhi, India: Prentice-Hall Private Ltd.

Ehigiamusoe, G., 2006a. "Principles and Practices of Microfinance", Paper presented at a Workshop organized by Central Bank of Nigeria for directors of proposed microfinance banks, At CBN Owerri Branch.

Ehigiamusoe, G., 2006b. "Risk Management in Microfinance" Paper presented at a Workshop organized by Central Bank of Nigeria for directors of proposed microfinance banks, At CBN Owerri Branch.

Guest, D. E., 1987. "Human Resource Management and Industrial Relations", 
Journal of Management Studies, 24, (5): Pp.503-521.

Harbinson, F.H., 1973. Human Resources as the Wealth of Nations, New York: Oxford University Press.

Hazell, P. and Lutz, E., 1998. "Integrating environmental and sustainability concerns into rural development policies", in Ernst Lutz et al. (Ed.) Agriculture and the Environment: Perspectives on sustainable rural Development, Washington D.C.: The World Bank.

Ikeanyibe M. O., 2002. "Human Resource Development and Utilization in The Community Banks (Enugu Zone)", Unpublished PhD Thesis, Dept of Public Administration \& Local Government, University of Nigeria Nsukka.

Lawler III, E. E., 1973. Motivation in Work Organizations, Monterey, California: Brooks/Cole Publishing Company

Manasseh, O.T.B., 1995. Bank Operations Dossier for Community Banks, Enugu: Ochumba Ltd.

Microfinancelnsights, March, 2008. "Focus On Human Resources: Finding the Key to HR Challenges",

http://www.microfinanceinsights.com

MicroStart

Monitor, 2007.

http://www.microcapital.org/new-wirenigeria-central-bank-predicts-450-of-700microfinance-institutions-will-survive-intothe-new-year/

Mullins, L. J., 2002. Management and Organizational Behaviour $6^{\text {th }}$ Ed., Great Britain, Pitman.

National Board for Community Banks, 2000. Community Banks Newsletter, 10, (3): Abuja: Public Relations Unit, NBCB

Nnadozie, P. A., 2003. "Public Policy Implementation: A Case Study of the National Poverty Eradication Programme (NAPEP) in Anambra State", Unpublished MPA dissertation submitted to the Department of Public Administration and
Local Government, University of Nigeria Nsukka.

Nwachukwu, C. C., 1998. Management: Theory and Practice, Onitsha: Africana-Fep

Okafor, F.O., 1992. "Role of Community Banks in Grassroots Development", Invited Paper Presented at the First Anniversary and Annual Conference of Community Banks, at Sheraton Hotels and Towers, Abuja

Ojo, F., Aderinto, A. and Fashoyin, T., 1986. Manpower Development and Utilization in Nigeria, Lagos: Lagos University Press.

Olaitan, S. O., 1995. "Promoting Skills Development and Productivity through Vocational Education in Rural Nigeria", Eboh, E.C., Okoye, C.U., and Ayichi, D. (Eds.), Rural Development in Nigeria: Concepts, Processes and Prospects, Enugu: Auto-Century.

Onyene, V. E., 2000. Interpersonal Skills for Effective Personnel Administrations: The Fads And The Facts, Lagos: Al-Mark Publishers Ltd.

Poole, M. and Warner, M., 2001. "Introducing human resource management", Poole, M. and Warner, M. (Eds) International Encyclopaedia for Business Management: Handbook of Human Resource Management, London: Thomson Learning.

PRISMS, 2005. "Governance Issues in Micro Finance", A paper presented at the International Year of Micro Finance (IYMC) Workshop", $16^{\text {th }}$ Dec. 2005, Abuja: USAID Nigeria Prisms Project.

Robinson, M. and Davidson, G., 2001. Chambers $21^{\text {st }}$ Century Dictionary Rvsd Ed., New Delhi: Allied Chambers (India) Ltd.

Shuler, R. S., 2001. "Human resource management' in Poole and Warner (Eds), International Encyclopaedia for Business Management: Handbook of Human Resource Management, London: Thomson Learning

Storey, J., 1989. "From Personnel Management to Human Resource Management", in Storey 
J. (Ed), New Perspectives on Human Resource Management, London: Routledge

Torrington, D. and Hall, L., 1991. Personnel Management: A New Approach, $2^{\text {nd }}$ Ed., Prentice-Hall.
Yesufu, T. M., 2000. The Human Factor in National Development: Nigeria, Ibadan: Spectrum Books Ltd. 